\title{
Factors influencing antibacterial activity of chitosan against Aeromonas hydrophila and Staphylococcus aureus
}

\author{
${ }^{*}$ Belgin Erdem ${ }^{1}$, Ergin Kariptaş ${ }^{2}$,Tayfun Kaya ${ }^{3}$, Şener Tulumoğlu ${ }^{4}$ and Özkan Görgülü ${ }^{5}$ \\ ${ }^{1}$ Department of Biology, Faculty of Arts and Sciences, Ahi Evran University, Bagbası Campus, 40100, Kırşehir, Turkey \\ ${ }^{2}$ Department of Medical Microbiology, Faculty of Medicine, Ahi Evran University, Bagbasi Campus, 40100, Kirşehir, Turkey \\ ${ }^{3}$ Department of Environmental Engineering, Faculty of Architecture and Engineering, Ahi Evran University, Bagbası Campus, 40100, Kırşehir, Turkey \\ ${ }^{4}$ Doctor Behçet Uz Hospital for Child Diseases Education and Research, 35210 Alsancak, Turkey \\ ${ }^{5}$ Department of Biostatistics and Medical Informatics, Faculty of Medicine, Ahi Evran University., Bagbasi Campus, 40100, Kirşehir, Turkey
}

\begin{abstract}
In this study, the effect of the incubation time, incubation temperature, $\mathrm{pH}$, metal and sodium ions on the antibacterial activity of chitosan against food borne spoilage bacteria focused. Aeromonas hydrophila and Staphylococcus aureus, were used as two food borne bacteria. Acetic acid was used dissolving of chitosan. Results showed that chitosan solution at $5 \mathrm{mg} / \mathrm{mL}$ significantly inhibited the growth of $A$. hydrophila and $S$. aureus in presence of time, $\mathrm{pH}$ and metal ions $(\mathrm{p}<0.01)$. However, temperature did not significantly affect the antibacterial activity $\left(4^{\circ} \mathrm{C}, 25^{\circ} \mathrm{C}\right.$ and $\left.37^{\circ} \mathrm{C}\right)(\mathrm{p}>0.01)$. Chitosan activity increased with increasing incubation time. The influence of below $\mathrm{pH} 6$ on the antibacterial activity of chitosan was significantly influenced (p<0.01). The addition of Ba+2 reduced chitosan activity against $A$. hydrophila while the addition of $\mathrm{Ca}^{+2}$ have increased chitosan activity against $S$. aureus. Sodium ions at a concentration of $25 \mathrm{mM}$ reduced chitosan activity against $S$. aureus. These results show that chitosan can be used food industry to prevent the development of spoilage bacteria.
\end{abstract}

Key Words: Chitosan, antibacterial activity, incubation time, incubation temperature, $\mathrm{pH}$, metal and sodium ions.

\section{INTRODUCTION}

Among food-borne risks microbial hazards are the top when the number of microorganisms exceeds a definite level. The food becomes exhaustless and becomes risky for human health. Especially, the foods may be infected by toxic and pathogenic bacteria such as Escherichia coli, Staphylococcus aureus, Aeromonas hydrophila and Pseudomonas aeruginosa. Currently, artificial food additives are used in order to prevent contamination of foods. However, they may cause impairment of human health. Hence, amount of use of these additives have been reduced and some of them have been prohibited. Moreover, additives which are obtained from natural resources have been started to be used instead of these artificial additives.

Although Chitin is a polymer of N-acetyl-Dglucosamine, chitosan is N-acetyl-D-glucosamine and Dglucosamine copolymer (Rinaudo, 2006; Shahidi, 2007). Chitosan is considered a compatible, non-antigenic, nontoxic, and biofunctional food additive (Novack et al., 2003). The pharmaceutical and food industry have received preservative and an important new material (Illum, 1998).

The use of chitosan as an antimicrobial material for food has been widely reported, for example, in bread (Lee et al., 2002), seafood (Tsai et al., 2002; López-Caballero et al., 2005), fruit and vegetables (Chien et al., 2007; Badawy and Rabea, 2009), meat (Sagoo et al., 2002; Rao et al., 2005), sausage (Lin and Chao, 2001; Soultos et al., 2008) and dairy products (Suman et al., 2010).

Chitosan has antimicrobial activity against foodborne bacteria, yeast and filamentous fungi (Sagoo et al.,
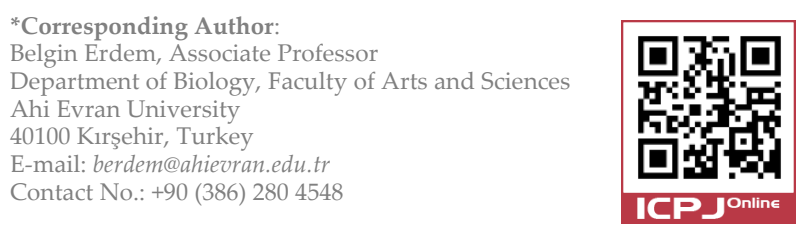

2002). Therefore, chitosan has been shown to inhibit food spoilage microorganisms such as Escherichia coli, Staphylococcus aureus and Candida sp. (Rhoades and Roller, 2000; Chung et al., 2005; Yang et al., 2005).

Furthermore, the chitosan showed antibacterial activity on dental caries connected Klebsiella pneumoniae and Bacillus subtilis (Fujiwara et al., 2004). Bacterial cell binding and DNA binding mechanisms arises antibacterial activity of chitosan (Chung and Chen, 2008). Another reported mechanism involves the interaction of diffused hydrolysis products with microbial DNA, which leads to an inhibition of the mRNA and protein synthesis (Hadwiger and Loschke, 1986).

The antimicrobial activity of chitosan has been shown to be affected by $\mathrm{pH}$, with higher activity observed at lower $\mathrm{pH}$ values, and to increase with rising temperature (No et al., 2002; Taha and Swailam, 2002). However, the presence of sodium ions has been reported to reduce chitosan's activity; a similar but more dramatic effect was obtained through the addition of other metal ions, probably due to formation of complexes between chitosan and metal ions (Taha and Swailam, 2002; Tsai and Su, 1999).

In this study is impacted the antibacterial activity of chitosan against Aeromonas hydrophila and Staphylococcus aureus as in vitro including $\mathrm{pH}$, incubation time, incubation temperature and metal ions.

\section{MATERIALS AND METHODS}

\section{Preparation of chitosan stock}

Chitosan (degree of N-deacetylation $80-85 \%$, from crab shells) was obtained from Sigma-Aldrich (USA). The tests were conducted set with chitosan and a control set without chitosan. Chitosan $(0.5 \mathrm{~g})$ was dissolved in 100 $\mathrm{mL} 1 \%$ acetic acid with $\mathrm{pH}$ adjusted to 5.2 with $1 \mathrm{~N} \mathrm{NaOH}$ (Li et al., 2008). After stirring at $160 \mathrm{rpm}$ for $24 \mathrm{~h}$ at room temperature, this resulting stock solution was autoclaved 
at $121^{\circ} \mathrm{C}$ for $20 \mathrm{~min}$. Sterile nutrient broth of $\mathrm{pH} 7.2$ was used as a control.

\section{Bacterial strains}

To obtain inocula for the examination, two strains of food spoilage bacteria, A. hydrophila (ATCC 7966) and S. aureus (ATCC 29213) were obtained from the the American Type Culture Collection (ATCC). Cultures were maintained by the transfer on nutrient agar medium. After cultivation and washing, cells were suspended and diluted in sterile saline $(0.85 \% \mathrm{NaCl})$ to an approximate concentration of $6.4 \times 10^{7} \mathrm{CFU} / \mathrm{mL}$ for $A$. hydrophila and $5.6 \times 10^{7} \mathrm{CFU} / \mathrm{mL}$ for $S$. aureus. These suspensions were used as the inocula for the time, temperature, $\mathrm{pH}$, chitosan-metal and chitosansodium ions experiments.

\section{Influence of environmental conditions on antibacterial activity of chitosan}

The experiment studies were carried out with different environmental conditions for time (4h, $8 \mathrm{~h}$ and $24 \mathrm{~h}$ ), temperature $\left(4^{\circ} \mathrm{C}, 25^{\circ} \mathrm{C}\right.$ and $\left.37^{\circ} \mathrm{C}\right), \mathrm{pH}(5-8)$, metal and sodium ions. Incubation time for antibacterial activity, 0.5 $\mathrm{ml}$ of bacterial cell suspension was transferred into an aseptic test tube containing $4.5 \mathrm{ml}$ of chitosan solution (final concentration: $5 \mathrm{mg} / \mathrm{mL}$ ) at $\mathrm{pH} 7$ and incubated at $37^{\circ} \mathrm{C}$ for variable times (4h, $8 \mathrm{~h}$ and $24 \mathrm{~h}$ ). The incubated solution was then plated on TSB agar and incubated at $37^{\circ} \mathrm{C}$ for $24 \mathrm{~h}$ to obtain viable cell counts. After incubation, the colonies were counted to analyze the bactericidal activity. All experiments were performed in triplicate.

Incubation temperature for antibacterial activity, 0.5 $\mathrm{ml}$ bacterial cells were transferred an aseptic test tube containing $4.5 \mathrm{ml}$ of chitosan solution (final concentration: $5 \mathrm{mg} / \mathrm{mL}$ ) at $\mathrm{pH} 7$ and incubated for $24 \mathrm{~h}$ at variable temperatures $\left(4^{\circ} \mathrm{C}, 25^{\circ} \mathrm{C}\right.$ and $\left.37^{\circ} \mathrm{C}\right)$. Following incubation with the chitosan, the solution was plated to TSB agar in order to obtain viable cell counts. All experiments were performed in triplicate.

Effect of $\mathrm{pH}$ on the antibacterial activity of chitosan, nutrient broth was adjusted to $5.0,6.0,7.0$ or 8.0 with a pH-meter (Metler Toledo 320, Halstead, UK) by adding dilute $\mathrm{HCl}$ or $\mathrm{NaOH}$ aqueous solution. Bacterial cell suspensions were incubated with chitosan at the different $\mathrm{pH}$ conditions (5.0-8.0), plated on TSB agar, and then incubated at $37^{\circ} \mathrm{C}$ for $24 \mathrm{~h}$. After incubation, the colonies were counted.

Effect of Metal Ions and $\mathrm{NaCl}$, chitosan $(5 \mathrm{mg} / \mathrm{mL})$ was added to bacteria cell suspension $\left(50 \mathrm{~mL}, 10^{7} \mathrm{cfu} / \mathrm{mL}\right)$ in nutrient broth and phosphate buffer $(5 \mathrm{mM}, \mathrm{pH} 7.0)$ containing 0 or $25 \mathrm{mM} \mathrm{MgCl}_{2}, \mathrm{BaCl}_{2}, \mathrm{CaCl}_{2}$ and $\mathrm{NaCl}$. The reaction mixtures were incubated for $24 \mathrm{~h}$ at variable temperatures $\left(4^{\circ} \mathrm{C}, 25^{\circ} \mathrm{C}\right.$ and $\left.37^{\circ} \mathrm{C}\right)$ and incubated at $37^{\circ} \mathrm{C}$ for variable times $(4 \mathrm{~h}, 8 \mathrm{~h}$ and $24 \mathrm{~h})$. Surviving cells were counted by spreading on nutrient agar plates .

\section{Statistical analysis}

Repeated Measures Analysis of variance was used to evaluate the data. Analyses were conducted with chitosan, temperature and $\mathrm{pH}$ applications as between subject factors and time as the within subject factor. As a result of the Repeated Measures Analysis of variance, DUNCAN multiple comparison test was used for grouping of between subject factor intervals that were significantly different. Bonferroni multiple comparison test was used for grouping within subject factors. SPSS 15.0 software was used in the statistical analyses. All analyses were run in triplicate for each replication (SAS, 2001).

\section{RESULTS AND DISCUSSION}

Effect of incubation time on the antibacterial activity of chitosan

The antibacterial activity of chitosan against $A$. hydrophila and S. aureus with respect to incubation time are shown in table 1.

After $4 \mathrm{~h}$ of incubation in chitosan, viable cell counts of $A$. hydrophila decreased by $0.10 \log \mathrm{CFU} / \mathrm{mL}$ while viable cell counts of $S$. aureus decreased by $0.20 \mathrm{log}$ $\mathrm{CFU} / \mathrm{mL}$ compared to the control. After $24 \mathrm{~h}$ of incubation in $5 \mathrm{mg} / \mathrm{mL}$ chitosan, A. hydrophila viable cell counts decreased by $2.30 \log \mathrm{CFU} / \mathrm{mL}$ compared to the control. Similarly, viable S. aureus decreased by $1.90 \mathrm{log}$

$\mathrm{CFU} / \mathrm{mL}$ was compared to the control and the large increase in the reduction of viability between the 4 and 24 $\mathrm{h}$ incubation times showed that a certain incubation time is required for the chitosan to exert its antibacterial effects.

The results of this study indicated that the activity of chitosan was affected by the incubation time, which is consistent with the result of $\mathrm{Li}$ et al. (2008), who found that a certain incubation time is required for chitosan to begin to inhibit bacterial growth.

Effect of temperature on the antibacterial activity of chitosan

The antibacterial activities of chitosan against strains of $A$. hydrophila and $S$. aureus at different temperatures are shown in table 2.

Temperature also has an effect on the antimicrobial activity of chitosan. Higher temperature $\left(37^{\circ} \mathrm{C}\right)$ has been shown to enhance its antimicrobial activity compared to refrigeration temperatures.

\section{Effect of $\mathbf{p H}$ on the antibacterial activity of chitosan}

The antibacterial activities of chitosan against A. hydrophi$l a$ and $S$. aureus at different incubation $\mathrm{pH}$ levels are shown in table 3 . For both strains, antibacterial activity was more pronounced at lower $\mathrm{pH}$ levels $(\mathrm{p}<0.01)$. Viable cells of $A$. hydrophila were reduced from their initial populations by $1.80-0.57 \log \mathrm{cfu} / \mathrm{mL}$. Similarly, S. aureus were reduced from their initial populations by $1.70-1.00$ $\log \mathrm{cfu} / \mathrm{mL}$.

The antimicrobial activity of chitosan becomes notable when $\mathrm{pH}$ decreases to 5-6. This is likely due to the fact that the amino groups of chitosan become positively ionized below $\mathrm{pH}$ 6. Unmodified chitosan is not antimicrobially active at $\mathrm{pH} 7$, likely due to lack dissolution and lack of positive charges on the amino groups (Chung et al., 2005). In this study, A. hydrophila and S. aureus were found to be less susceptible to chitosan at $\mathrm{pH} 8.0$, with a population reduction of $0.57-1.00 \log \mathrm{cfu} / \mathrm{mL}$, respectively. These results are slightly different from those reported by Chung et al., (2003), who found that the inhibition percentage of chitosan solution decreased with increasing of $\mathrm{pH}$ but dropped dramatically when the $\mathrm{pH}$ was higher than 6.0.

Effect of metal and sodium ions on the antibacterial activity of chitosan

The effects of metal ions on the antibacterial activity of chitosan towards A. hydrophila and S. aureus are shown in tables 4 and 5 .

The effect of chitosan on A. hydrophila and S. aureus with regard to metal and sodium ions decreased along with a rise in incubation temperature and incubation time. 
Table 1: Inhibitory effect of chitosans on growth of $A$. hydrophila and S. aureus after different time (pH: 7 , temperature: $37^{\circ} \mathrm{C}$ ).

\begin{tabular}{|c|c|c|c|c|c|}
\hline \multirow[b]{2}{*}{ Bacteria } & \multirow{2}{*}{$\begin{array}{c}\text { Bacteria cell } \\
\text { (cfu/mL) }\end{array}$} & \multirow{2}{*}{$\begin{array}{c}\text { Chitosan conc. } \\
(\mathrm{mg} / \mathrm{ml})\end{array}$} & \multicolumn{3}{|c|}{ Time (h) } \\
\hline & & & $4 \mathrm{~h}$ & $8 \mathrm{~h}$ & $24 \mathrm{~h}$ \\
\hline \multirow{3}{*}{ A. hydrophila } & \multirow{3}{*}{$6.4 \times 10^{7}$} & Control & $6.70 \pm 0.11$ & $6.40 \pm 0.19$ & $6.70 \pm 0.16$ \\
\hline & & 5 & $6.30 \pm 0.04$ & $5.50 \pm 0.28$ & $4.10 \pm 0.27$ \\
\hline & & & $6.50 \pm 0.20^{\mathrm{b}}$ & $5.95 \pm 0.45^{a}$ & $5.40 \pm 1.30^{\mathrm{a}}$ \\
\hline \multirow{3}{*}{ S. aureus } & \multirow{3}{*}{$5.6 \times 10^{7}$} & Control & $5.40 \pm 0.07$ & $5.80 \pm 0.15$ & $5.40 \pm 0.07$ \\
\hline & & 5 & $5.40 \pm 0.05$ & $3.50 \pm 0.21$ & $3.70 \pm 0.28$ \\
\hline & & & $5.40 \pm 0.00^{\mathrm{b}}$ & $4.65 \pm 1.15^{\mathrm{a}}$ & $4.55 \pm 0.85^{\mathrm{a}}$ \\
\hline
\end{tabular}

$\overline{\mathrm{a}, \mathrm{b}}$ means followed by different superscripts differ $(\mathrm{p}<0.05)$.

Table 2: Inhibitory effect of chitosans on growth of A. hydrophila and S. aureus after different temperature (pH: 7, time: 24 h).

\begin{tabular}{|c|c|c|c|c|c|}
\hline \multirow{2}{*}{ Bacteria } & \multirow{2}{*}{$\begin{array}{c}\text { Bacteria cell } \\
(\mathrm{cfu} / \mathrm{mL})\end{array}$} & \multirow{2}{*}{$\begin{array}{l}\text { Chitosan conc. } \\
(\mathrm{mg} / \mathrm{ml})\end{array}$} & \multicolumn{3}{|c|}{ Temperature $\left({ }^{\circ} \mathrm{C}\right)$} \\
\hline & & & $4^{\circ} \mathrm{C}$ & $25^{\circ} \mathrm{C}$ & $37^{\circ} \mathrm{C}$ \\
\hline \multirow{3}{*}{ A. hydrophila } & \multirow{3}{*}{$6.4 \times 10^{7}$} & Control & $6.60 \pm 0.09$ & $6.60 \pm 0.09$ & $6.50 \pm 0.25$ \\
\hline & & 5 & $5.30 \pm 0.37$ & $5.40 \pm 0.32$ & $5.20 \pm 0.35$ \\
\hline & & & $5.95 \pm 0.65^{\mathrm{a}}$ & $6.00 \pm 0.60^{\mathrm{a}}$ & $5.85 \pm 0.65^{\mathrm{a}}$ \\
\hline \multirow{3}{*}{ S. aureus } & \multirow{3}{*}{$5.6 \times 10^{7}$} & Control & $5.50 \pm 0.10$ & $5.50 \pm 0.12$ & $5.50 \pm 0.12$ \\
\hline & & 5 & $4.20 \pm 0.34$ & $4.28 \pm 0.31$ & $4.20 \pm 0.32$ \\
\hline & & & $4.85 \pm 0.65^{\mathrm{a}}$ & $4.89 \pm 0.61^{\mathrm{a}}$ & $4.85 \pm 0.65^{\mathrm{a}}$ \\
\hline
\end{tabular}

a means followed by different superscripts differ $(\mathrm{p}<0.05)$.

Table 3: Inhibitory effect of chitosans on growth of $A$. hydrophilaand S. aureus after different $\mathrm{pH}$ (temperature: $37^{\circ} \mathrm{C}$, time: $24 \mathrm{~h}$ ).

\begin{tabular}{|c|c|c|c|c|c|c|}
\hline \multirow{2}{*}{ Bacteria } & \multirow{2}{*}{$\begin{array}{l}\text { Bacteria cell } \\
\text { (cfu/mL) }\end{array}$} & \multirow{2}{*}{$\begin{array}{l}\text { Chitosan conc. } \\
(\mathrm{mg} / \mathrm{ml})\end{array}$} & \multicolumn{4}{|c|}{$\mathrm{pH}$} \\
\hline & & & 5 & 6 & 7 & 8 \\
\hline \multirow{3}{*}{ A. hydrophila } & \multirow{3}{*}{$6.4 \times 10^{7}$} & Control & $6.50 \pm 0.00$ & $6.60 \pm 0.09$ & $6.50 \pm 0.14$ & $6.60 \pm 0.28$ \\
\hline & & 5 & $4.60 \pm 0.44$ & $5.00 \pm 0.50$ & $5.73 \pm 0.30$ & $5.83 \pm 0.15$ \\
\hline & & & $5.55 \pm 0.95^{\mathrm{a}}$ & $5.80 \pm 0.80^{\mathrm{a}, \mathrm{b}}$ & $6.12 \pm 0.38^{a, b}$ & $6.22 \pm 0.38^{b}$ \\
\hline \multirow{3}{*}{ S. aureus } & \multirow{3}{*}{$5.6 \times 10^{7}$} & Control & $5.40 \pm 0.10$ & $5.50 \pm 0.07$ & $5.50 \pm 0.12$ & $5.70 \pm 0.19$ \\
\hline & & 5 & $3.90 \pm 0.43$ & $4.00 \pm 0.44$ & $4.30 \pm 0.33$ & $4.60 \pm 0.23$ \\
\hline & & & $4.65 \pm 0.75^{\mathrm{a}}$ & $4.75 \pm 0.75^{a}$ & $4.90 \pm 0.60 \mathrm{a}, \mathrm{b}$ & $5.15 \pm 0.55^{\mathrm{b}}$ \\
\hline
\end{tabular}

a,b means followed by different superscripts differ $(\mathrm{p}<0.05)$.

Table 4: Effects of chitosan-metal and chitosan-sodium ions on the growth of A. hydrophilaand S.aureus at different times (pH: 7, temperature: $37^{\circ} \mathrm{C}$ ).

\begin{tabular}{|c|c|c|c|c|c|}
\hline \multirow{2}{*}{ Bacteria } & \multirow{2}{*}{$\begin{array}{l}\text { Bacteria cell } \\
\text { (cfu/mL) }\end{array}$} & \multirow{2}{*}{ Metal ions Conc. (25mM) } & \multicolumn{3}{|c|}{ Time (h) } \\
\hline & & & $4 h$ & $8 \mathrm{~h}$ & $24 \mathrm{~h}$ \\
\hline \multirow{6}{*}{ A. hydrophila } & \multirow{6}{*}{$6.4 \times 10^{7}$} & Control & $7.22 \pm 0.03$ & $7.25 \pm 0.10$ & $7.12 \pm 0.19$ \\
\hline & & $\mathrm{MgCl}_{2}$ & $6.60 \pm 0.05$ & $4.93 \pm 0.31$ & $4.07 \pm 0.47$ \\
\hline & & $\mathrm{BaCl}_{2}$ & $5.97 \pm 0.39$ & $4.83 \pm 0.67$ & $3.97 \pm 0.23$ \\
\hline & & $\mathrm{CaCl}_{2}$ & $5.83 \pm 0.66$ & $3.47 \pm 0.21$ & $2.27 \pm 0.08$ \\
\hline & & $\mathrm{NaCl}$ & $5.20 \pm 0.55$ & $4.57 \pm 0.31$ & $3.70 \pm 0.26$ \\
\hline & & & $6.16 \pm 0.34^{c}$ & $5.01 \pm 0.16^{\mathrm{b}}$ & $4.23 \pm 0.79^{a}$ \\
\hline \multirow{6}{*}{ S. aureus } & \multirow{6}{*}{$5.6 \times 10^{7}$} & Control & $6.27 \pm 0.11$ & $6.46 \pm 0.09$ & $6.34 \pm 0.08$ \\
\hline & & $\mathrm{MgCl}_{2}$ & $5.33 \pm 0.12$ & $5.03 \pm 0.31$ & $4.07 \pm 0.59$ \\
\hline & & $\mathrm{BaCl}_{2}$ & $5.13 \pm 0.08$ & $4.40 \pm 0.55$ & $3.27 \pm 0.96$ \\
\hline & & $\mathrm{CaCl}_{2}$ & $4.97 \pm 0.39$ & $3.50 \pm 0.91$ & $3.23 \pm 0.08$ \\
\hline & & $\mathrm{NaCl}$ & $3.30 \pm 0.49$ & $3.13 \pm 0.54$ & $2.83 \pm 0.46$ \\
\hline & & & $5.00 \pm 0.48^{c}$ & $4.50 \pm 0.59^{b}$ & $3.95 \pm 0.63^{a}$ \\
\hline
\end{tabular}

Initial citosan concentration was used as $5 \mathrm{mg} / \mathrm{ml}$. a,b,c means followed by different superscripts differ $(\mathrm{p}<0.05)$.

Table 5: Inhibitory effect of chitosans on growth of A. hydrophila and S.aureus after different temperature (pH: 7, time; 24 h).

\begin{tabular}{|c|c|c|c|c|c|}
\hline \multirow{2}{*}{ Bacteria } & \multirow{2}{*}{$\begin{array}{c}\text { Bacteria cell } \\
(\mathrm{cfu} / \mathrm{mL})\end{array}$} & \multirow{2}{*}{ Metal ions Conc. $(25 \mathrm{mM})$} & \multicolumn{3}{|c|}{ Temperature $\left({ }^{\circ} \mathrm{C}\right)$} \\
\hline & & & $4^{\circ} \mathrm{C}$ & $25^{\circ} \mathrm{C}$ & $37^{\circ} \mathrm{C}$ \\
\hline \multirow{6}{*}{ A. hydrophila } & \multirow{6}{*}{$6.4 \times 10^{7}$} & Control & $7.15 \pm 0.12$ & $7.31 \pm 0.04$ & $7.13 \pm 0.17$ \\
\hline & & $\mathrm{MgCl}_{2}$ & $5.17 \pm 0.54$ & $5.50 \pm 0.47$ & $5.70 \pm 1.00$ \\
\hline & & $\mathrm{BaCl}_{2}$ & $3.87 \pm 1.21$ & $4.63 \pm 0.76$ & $4.00 \pm 1.27$ \\
\hline & & $\mathrm{CaCl}_{2}$ & $3.73 \pm 0.39$ & $3.83 \pm 0.80$ & $5.50 \pm 0.70$ \\
\hline & & $\mathrm{NaCl}$ & $3.90 \pm 0.35$ & $5.03 \pm 0.66$ & $4.53 \pm 0.38$ \\
\hline & & & $4.76 \pm 0.65^{\mathrm{a}}$ & $5.26 \pm 0.58^{b}$ & $5.37 \pm 0.53^{b}$ \\
\hline \multirow{6}{*}{ S. aureus } & \multirow{6}{*}{$5.6 \times 10^{7}$} & Control & $6.32 \pm 0.06$ & $6.25 \pm 0.09$ & $6.50 \pm 0.11$ \\
\hline & & $\mathrm{MgCl}_{2}$ & $4.6 \pm 0.75$ & $5.37 \pm 0.08$ & $4.20 \pm 0.52$ \\
\hline & & $\mathrm{BaCl}_{2}$ & $3.93 \pm 0.58$ & $4.60 \pm 0.60$ & $5.33 \pm 0.08$ \\
\hline & & $\mathrm{CaCl}_{2}$ & $3.23 \pm 0.98$ & $3.17 \pm 0.53$ & $4.50 \pm 0.47$ \\
\hline & & $\mathrm{NaCl}$ & $3.00 \pm 0.15$ & $2.27 \pm 0.12$ & $4.00 \pm 0.15$ \\
\hline & & & $4.22 \pm 0.59^{a}$ & $4.33 \pm 0.72^{\mathrm{a}}$ & $4.91 \pm 0.45^{\mathrm{b}}$ \\
\hline
\end{tabular}

Initial chitosan concentration was used as $5 \mathrm{mg} / \mathrm{ml}$. a,b means followed by different superscripts differ $(\mathrm{p}<0.05)$. 
Divalent cations at concentrations of $25 \mathrm{mM}$ reduced the bactericidal effect of chitosan on A. hydrophila and $S$. aureus, the most effective being $\mathrm{Ba}^{+2}$. $\mathrm{Na}^{+}$ion at $25 \mathrm{mM}$ also reduced the activity of chitosan against A. hydrophila and S. aureus.

The addition of metal ions decreased the antimicrobial activity of $5 \mathrm{mg} / \mathrm{mL}$ chitosan was enhanced by sodium ions. The surviving cell numbers A. hydrophila decreased by $2.91 \log \mathrm{CFU} / \mathrm{mL}$ after incubation with chitosan in the presence of sodium ions for $24 \mathrm{~h}$. Under these conditions, the surviving cell numbers $S$. aureus decreased by $3.61 \log$ CFU/mL.

\section{CONCLUSION}

Consequently, chitosan is a potential bactericidal against food spoilage bacteria, under various environmental conditions.

We have found that $0.50 \%$ chitosan is sufficient to inhibit growth and to inactivate the production of $A$. hydrophila and $S$. aureus. Furthermore, the bactericidal activities of chitosan against $A$. hydrophila and S. aureus are affected by factors including temperature, time, $\mathrm{pH}$ and certain salts. In this context, chitosan can be employed as a preventing or remedial agent to avoid bacterial food spoilage. In particular, the results of this study showed that chitosan has a strong antibacterial activity against $A$. hydrophila and $S$. aureus, which will be helpful in the control of fruit and vegetable contamination. This study demonstrates the potential of chitosan an alternative natural product, to use for synthetic food additive replacement. While this study clearly shows that chitosan can be used as a natural preservative for the food industry, there exist many opportunities for further study and refinement.

\section{REFERENCES}

Aiedeh, K. and Taha M.O. (2001) Synthesis of iron-crosslinked chitosan succinate and iron-crosslinked hydroxamated chitosan succinate and their in vitro evaluation as potential matrix materials for oral theophylline sustained-release beads. Eur. J. Pharm. Sci., Volume 13, Pages 159-168. [DOI]

Badawy, M.E.I. and Rabea, E.I. (2009) Potential of the biopolymer chitosan with different molecular weights to control postharvest gray mold of tomato fruit. Postharvest Biol. Technol, Volume 51, Pages 110-117. [DOI]

Chien P.J., Sheu F. and Lin H.R. (2007) Coating citrus (Murcott tangor) fruit with low molecular weight chitosan increases postharvest quality and shelf life. Food. Chem., Volume 100, 1 Pages 160-1164. [DOI]

Chung Y.C. and Chen C.Y. (2008) Antibacterial characteristics and activity of acid-soluble chitosan. Bioresour.Technol.,Volume 99, Pages 2806-14. [DOI]

Chung Y.C., Kuo C.L. and Chen C.C. (2005) Preparation and important functional properties of water-soluble chitosan produced through Maillard reaction. Bioresource Technol., Volume 96, 1 Pages 473-1482. [DOI]

Chung Y.C., Wang H.L, Chen Y.M. and Li S.L. (2003) Effect of abiotic factors on the antibacterial activity of chitosan against waterborne pathogens. Bioresource Technol,. Volume 88, Pages 179-184. [DOI]

Fujiwara M., Hayashi Y. and Ohara N. (2004) Inhibitory effect of watersoluble chitosan on growth of Streptococcus mutans. New Microbiol., Volume 27, Pages 83-86.

Hadwiger, L.A., Kendra,D.F., Fristensky, B.W. \& Wagoner, W. (1986) Chitosan both activates genes in plants and inhibits RNA synthesis in fungi, In: R. Muzzarelli, C. Jeuniaux, G.W. Gooday, Chitin in Nature and Technology. (pp. 209) Plenum Pres, New York. [DOI]

Illum L. (1998) Chitosan and its uses as a pharmaceutical excipient. Pharm Res., Volume 15, 1 Pages 326-1331. [DOI]

Kong M, Chen X.G., Liu C.S., Liu C.G., Meng X.H. and Yu L.J. (2008a) Antibacterial mechanism of chitosan microspheres in a solid dispersing system against E. coli. Colloids and Surfaces: B Biointerfaces, Volume 65, Pages 197-202. [DOI]
Kong M, Chen X.G. Liu C.S., Yu L.J., Ji Q X, Xue Y.P., Cha D.S. and Park H.J. (2008b) Preparation and antibacterial activity of chitosan microspheres in a solid dispersing system. Frontiers of Materials Science in China, Volume 2, Pages 214-220. [DOI]

Lee H.Y., Kim S.M., Kim J.Y., Youn S.K., Choi J.S., Park S.M. and Ahn D.H (2002) Effect of addition of chitosan on improvement for shelf-life of bread. J. Korean Soc. Food Sci. Nutr., Volume 31, Pages 445-450. [DOI]

Li B., Wang X., Chen R.X., Huangfu W.G. and Xie G.L. (2008) Antibacterial activity of chitosan solution against Xanthomonas pathogenic bacteria isolated from Euphorbia pulcherrima. Carbohydr. Poly., Volume 72, Pages 287-292. [DOI]

Lin K.W. and Chao J.Y. (2001) Quality characteristics of reduced-fat Chinese-style sausage as related to chitosan's molecular weight. Meat Sci., Volume 59, 343-351. [DOI]

López-Caballero M.E., Gómez-Guillén M.C., Pérez-Mateos M. and Montero P. (2005) A chitosan-gelatin blend as a coating for fish patties. Food Hydrocol., Volume 19, Pages 303-311. [DOI]

No H.K., Park N.Y., Lee S.H., Hwang H.J. and Meyers S.P. (2002) Antibacterial activities of citosans and chitosan oligomers with different molecular weights on spoilage bacteria isolated from tofu. J. Food Sci., Volume 67, Pages 1511-1514. [DOI]

No H.K., Kim S.H., Lee S.H. Park N.Y. and Prinyawiwatkul W. (2006) Stability and antibacterial activity of chitosan solutions affected by storage temperature and time. Carbohydr Polym., Volume 65, Pages 174-178. [DOI]

Novak, K. Cupp, M..J. and Tracy, T.S. (2003) Chitosan. In: M. J., Cupp, T.S. Tracy, Dietary Supplements Toxicology and Clinical Pharmacology (pp.33-40). Humana Press, Totowa, NJ, USA. [DOI]

Papineau A.M., Hoover D.G., Knorr D., and Farkas D.F. (1991) Antimicrobial effect of watersoluble chitosans with high hydrostatic pressure. Food Biotechnol., Volume 5, Pages 45-57. [DOI]

Raafat D., and Sahl H.G. (2009) Chitosan and its antimicrobial potential-a critical literature survey. Microb Biotechnol., Volume 2, Pages 186-201. [DOI]

Rao S.M., Chander R. and Sharma A. (2005) Development of shelf-stable intermediate- moisture meat products using active edible chitosan coating and irradiation. J. Food Sci., Volume 70, Pages 325-331. [DOI]

Rhodes J.A, and Roller S. (2000) Antimicrobial actions of degraded and native chitosan against spoilage organisms in laboratory media and foods. Appl. Environ. Microbiol,. Volume 66, Pages 80-86. [DOI]

Rinaudo M. (2006) Chitin and chitosan: Properties and applications. Prog. Polym. Sci., Volume 31, Pages 603-632. [DOI]

Sagoo S., Board R., and Roller S. (2002) Chitosan inhibits growth of spoilage micro-organisms in chilled pork products. Food Microbiol., Volume 19, Pages 175-182. [DOI]

SAS. (2001) SAS User's Guide: Statistics (Version 8 Eds.). SAS Institute, Cary, NC.

Shahidi, F. (2007). Chitin and chitosan from marine by products. In: F. Shahidi, Maximizing the Value of Marine By-products (pp.340-373). Abington, Woodhead Publishing limited.

Soultos N., Tzikas Z., Abrahim A., Georgantelis D., and Ambrosiadis I (2008) Chitosan effects on quality properties of Greek style fresh pork sausages, Meat Sci., Volume 80, 1 Pages 1150-1156. [DOI]

Sudarshan N.R., Hoover D.G., and Knorr D. (1992) Antibacterial action of chitosan Food. Biotechnol., Volume 6, Pages 257-272. [DOI]

Suman S.P.I., Mancini R.A., Joseph P., Ramanathan R., Konda M.K., Dady G., and Yin S. (2010) Packaging-specific influence of chitosan on color stability and lipid oxidation in refrigerated ground beef. Meat Sci., Volume 86, Pages 994-998. [DOI]

Taha S.M., and Swailam H.M. (2002) Antibacterial activity of chitosan against Aeromonas hydrophila. Nahrung, Volume 46, Pages 337-340. [DOI]

Tsai G.J., and Su W.H. (1999) Antibacterial activity of shrimp chitosan against Escherichia coli, J. Food Prot., Volume 62, Pages 239- 243.

Tsai G.J., SU H., Chen H.C., and Pan C.L. (2002) Antimicrobial activity of shrimp chitin and chitosan from different treatments and applications of fish preservation. Fisheries Sci., Volume 68, 1 Pages 170-177. [DOI]

Yang T.C., Chou C.C. and Li C.F. (2005) Antibacterial activity of Nalkylated disaccharide chitosan derivatives. Int. J. Food Microbiol., Volume 97, Pages 237-245. [DOI] 